(c) American Dairy Science Association, 2006.

\title{
Algorithms for Dairy Barn Design: Resting, Feeding, and Exercise
}

\author{
M. E. Fernández, ${ }^{\star 1}$ R. A. Mariño, ${ }^{*}$ and X. C. Carreira* \\ *Department of Agroforestry Engineering, University of Santiago de Compostela, 27002 Lugo, Spain
}

\begin{abstract}
This study presents a series of algorithms designed to assist farmers and other decision-makers in the design of dairy cattle housing. Four algorithms have been developed, each for a different basic design (2 rows head-to-head, 2 rows head-to-wall, 3 rows, or rows perpendicular to feed alley). Each algorithm requires input of herd size and various other parameters (e.g., freestall width), depending on the design; the output gives barn layout and overall size, thus facilitating comparison of designs in terms of financial cost and animal welfare. Although these algorithms have been developed primarily for small family farms in Galicia (northwest Spain) with herd sizes of up to 250 , they could be useful for herds of any size, because herd size is an input parameter. We consider that these algorithms are useful tools for dairy farm planning, and they can be readily incorporated into personal computer applications, greatly facilitating their application.
\end{abstract}

Key words: free stall barn, design, dimensions

\section{INTRODUCTION}

The design of housing for dairy cattle is based on 2 types of criteria. The primary design criterion is to create an optimally healthy and agreeable environment for the cattle, suitably isolated from the exterior. The second important criterion is to create housing optimized for cattle management. Therefore, there is a requirement for adequate comfort (affecting health, Bowell et al., 2003; and productivity, Cook and Nordlund, 2004; von Borell, 1999). Comfortable housing is necessary to facilitate natural behavior of cows (related to resting, feeding, freedom of movement, movement behavior, or social behavior; Anonymous, 2001) and to avoid aggressive behavior and problems in the herd. Minimum measurements in the barn (for resting, exercise, feeding, and other activities) are necessary to achieve this (see Table 1 for recommended dimensions). There is also a requirement for animal management (Hansen, 2000).

Received June 23, 2005.

Accepted February 3, 2006.

${ }^{1}$ Corresponding author: melena@lugo.usc.es
To this end, the design of dairy cattle housing should closely reflect working procedures (Karszes, 2000; Bewley et al., 2001). Important aspects to be taken into account include feeding, milking, and cleaning procedures, as well as reproduction and health. Ideally, the design should be specifically created for each individual dairy farming operation, which requires detailed previous study of working procedures and careful planning (Buxadé Carbó, 1997; Bickert, 2000; Tyson, 2000; Arana et al., 2002). Several authors have produced guidelines for design once working procedures have been characterized and housing needs established (Buxadé Carbó, 1997; Bickert et al., 2000; Arana et al., 2002).

However, guidelines of this type may be difficult to apply to some types of farms, including small familyrun operations. This is certainly the case in the region of Galicia in northwest Spain, where dairy farming is one of the most important agricultural activities. Most dairy farms in this region are small family-run operations. According to the Galician Statistics Institute, there were 32,429 dairy-farming operations in the region in 2001 , of which only $28 \%$ had more than 20 cows, and only $10 \%$ more than 50 cows. However, there is a long-term trend toward larger farms: between 1993 and 2001, the number of farms with fewer than 50 cows dropped by $60 \%$, whereas between 2000 and 2001 the number of farms with more than 50 cows increased by more than $200 \%$.

Nevertheless, despite this long-term trend, there are still many family-run dairy farms in our region, so there is a clear need to develop housing design procedures suitable for farms with $<100$ cows, which may also be useful for larger dairies.

In parallel with the increasing farm size and modernization of dairy farming procedures in Galicia over recent decades, tie-stall barns have increasingly been replaced by free-stall barns. As noted by Carreira Pérez (1996), the construction of free-stall barns began in Galicia in the second half of the 1980s; until 1985, freestall barns represented only about $25 \%$ of the total, but between 1985 and 1990 about 36\% of newly constructed barns were free-stall barns.

In view of this situation, we created a series of algorithms to assist farmers and other decision-makers in the design of dairy cattle housing. These algorithms permit the generation of distributional solutions on the 
Table 1. Barn dimensions recommended in different published studies

\begin{tabular}{|c|c|c|c|c|c|c|c|}
\hline \multirow[b]{2}{*}{ Characteristic } & \multicolumn{6}{|c|}{ Reference } & \multirow[b]{2}{*}{$\begin{array}{l}\text { Alonso, } \\
2002\end{array}$} \\
\hline & $\begin{array}{l}\text { Adams et al., } \\
1995^{1}\end{array}$ & $\begin{array}{l}\text { Anonymous, } \\
2001^{2}\end{array}$ & $\begin{array}{l}\text { Bickert et al., } \\
2000^{3}\end{array}$ & $\begin{array}{l}\text { Carreira, } \\
1996\end{array}$ & $\begin{array}{l}\text { Graves, } \\
1995\end{array}$ & $\begin{array}{l}\text { Arana et al., } \\
2002\end{array}$ & \\
\hline Length & $2.28-2.44$ & $2.45-2.60$ & $2.29-2.59$ & - & - & - & - \\
\hline Width & 1.22 & 1.20 & $1.22-1.32$ & - & - & - & - \\
\hline No. of free stalls in line without cross alleys & - & 20 & $30-40$ & 30 & - & - & - \\
\hline Cross alley width, $\mathrm{m}$ & - & - & - & - & - & - & - \\
\hline \multicolumn{8}{|l|}{ Alley width, m } \\
\hline Feed alley & - & $3.20-3.60$ & - & 3.75 & 3.60 & - & - \\
\hline Free stall alley & - & 2.40 & - & 2.50 & 2.40 & - & - \\
\hline \multicolumn{8}{|l|}{ Feeding space requirements, $\mathrm{m}$} \\
\hline Feed driveway width & - & - & 3.70 & 4.00 & 3.70 & - & - \\
\hline Feeding table width & - & 0.90 & - & $0.90-1.0$ & - & - & - \\
\hline Space per cow & - & $0.65-0.75$ & $0.66-0.76$ & $0.70-0.80$ & - & - & - \\
\hline \multicolumn{8}{|l|}{ Waterers: location and number } \\
\hline No. of cows per pen ${ }^{6}$ & 25 & 30 & - & $20-30$ & - & - & - \\
\hline Pen surface, $\mathrm{m}^{2}$ & - & 10 & - & 12 & - & - & - \\
\hline \multicolumn{8}{|l|}{ Milking space requirements, $\mathrm{m}^{2} / \mathrm{cow}$} \\
\hline Holding area & - & 1.50 & - & - & & $1.20-1.50$ & 1.60 \\
\hline $\begin{array}{l}{ }^{1} \text { Cows between } 590 \text { and } 730 \mathrm{~kg} . \\
{ }^{2} \text { For large breeds. } \\
{ }^{3} \text { Cows of more than } 680 \mathrm{~kg} . \\
{ }^{4} \text { Maximum number of cows per waterer. } \\
{ }^{5} \text { Cows }(>600 \mathrm{~kg} \text { ) per meter of waterer. } \\
{ }^{6} \text { Individual pen. }\end{array}$ & & & & & & & \\
\hline
\end{tabular}

basis of various parameters, thus optimizing the final design. They are applicable in the design of barns for new construction, but also for adaptation and extension of existing barns in which the final dimensions are known and the aim is to optimize use of the existing space. We considered only the resting and feeding areas, although the final decision procedure will involve consideration of other areas (milking, maternity, etc.).

\section{MATERIALS AND METHODS}

The methodology of the study was as follows: 1) definition of the general parameters of design, 2) identification of parameters to be considered, 3) definition of the functional areas of study, 4) analysis of variation in layouts in these functional areas, depending on the starting parameters, and 5) development of the design algorithms.

In the first phase of development of the algorithms, we took those elements of internal distribution that define the stable layout as our starting point. These elements, features, and dimensions must consider cowspecific factors (size and behavior), cow welfare, and good herd management. The importance of stalls with

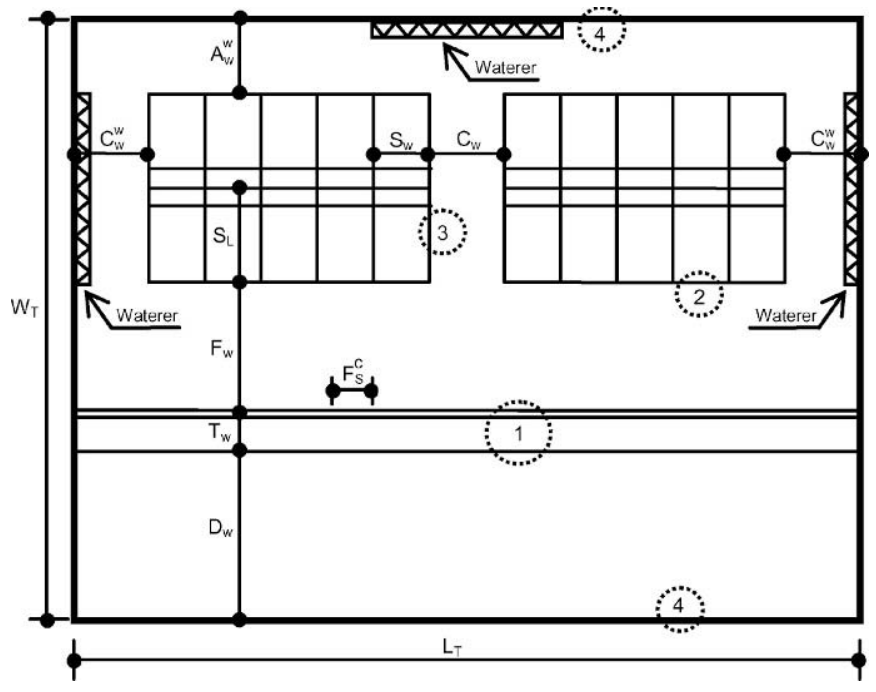

Figure 1. Two-row head-to-head design: $A_{W}^{W}=$ free-stall alley width (with waterers); $\mathrm{C}_{\mathrm{W}}=$ cross-alley width (without waterers); $\mathrm{C}_{\mathrm{W}}^{\mathrm{W}}=$ cross-alley width (with waterers); $\mathrm{D}_{\mathrm{W}}=$ driveway width; $\mathrm{F}_{\mathrm{W}}=$ feed alley width; $\mathrm{F}_{\mathrm{S}}^{\mathrm{c}}=$ feeding space per cow; $\mathrm{L}_{\mathrm{T}}=$ total outside barn length; $\mathrm{S}_{\mathrm{L}}=$ stall length; $\mathrm{S}_{\mathrm{W}}=$ stall width; $\mathrm{T}_{\mathrm{W}}=$ feeding table width; $\mathrm{W}_{\mathrm{T}}=$ total outside barn width; 1 = feeding area; 2 = free stall front; $3=$ free stall side; 4 = wall of barn. 


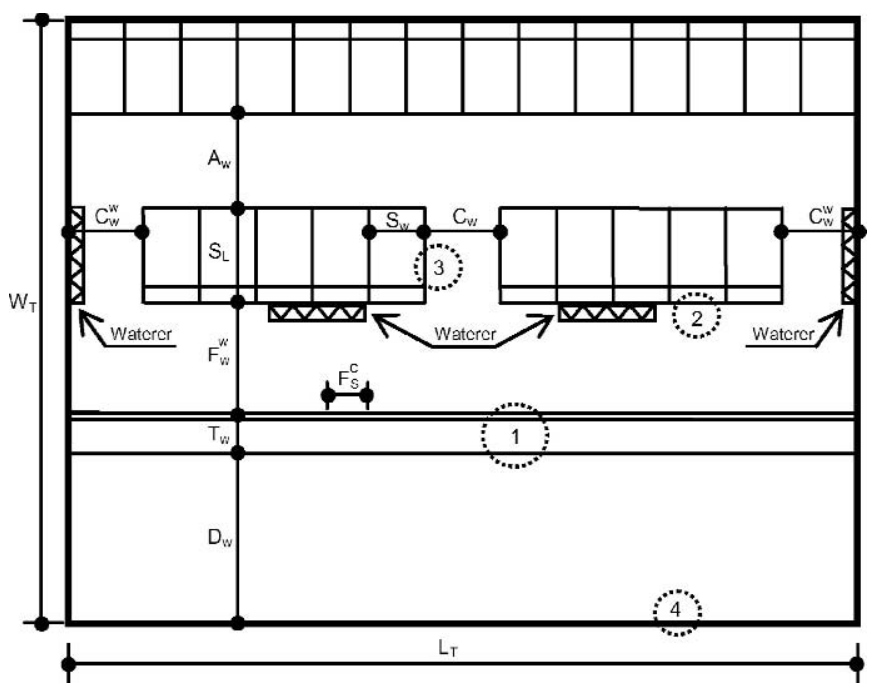

Figure 2. Two-row head-to-wall design: $A_{W}=$ free stall alley width; $\mathrm{C}_{\mathrm{W}}=$ cross alley width (without waterers); $\mathrm{C}_{\mathrm{W}}^{\mathrm{W}}=$ cross alley width (with waterers); $\mathrm{D}_{\mathrm{W}}=$ driveway width; $\mathrm{F}_{\mathrm{W}}^{\mathrm{W}}=$ feed alley width (with waterers); $\mathrm{F}_{\mathrm{S}}^{\mathrm{c}}=$ Feeding space per cow; $\mathrm{L}_{\mathrm{T}}=$ total outside barn length; $\mathrm{S}_{\mathrm{L}}=$ stall length; $\mathrm{S}_{\mathrm{W}}=$ stall width; $\mathrm{T}_{\mathrm{W}}=$ feeding table width $; \mathrm{W}_{\mathrm{T}}=$ total outside barn width; 1 = feeding area; 2 = free stall front; $3=$ free stall side; 4 = wall of barn.

adequate characteristics has been noted by various authors (stall dimensions, Tucker et al., 2004; Veissier et al., 2004; bedding material and other characteristics,

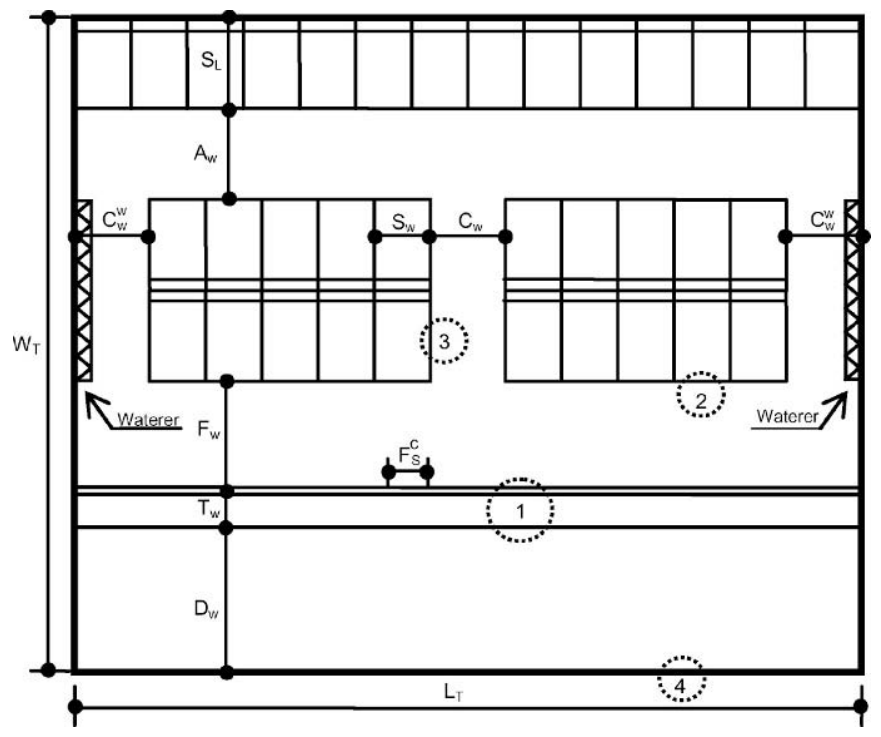

Figure 3. Three-row design: $A_{W}=$ free stall alley width; $C_{W}=$ cross alley width (without waterers); $\mathrm{C}_{\mathrm{W}}^{\mathrm{W}}=$ cross alley width (with waterers); $D_{\mathrm{W}}=$ driveway width $; F_{\mathrm{W}}=$ feed alley width; $F_{\mathrm{S}}^{\mathrm{c}}=$ feeding space per cow $\mathrm{L}_{\mathrm{T}}=$ total outside barn length; $\mathrm{S}_{\mathrm{L}}=$ stall length $; \mathrm{S}_{\mathrm{W}}=$ stall width; $\mathrm{T}_{\mathrm{W}}=$ feeding table width; $\mathrm{W}_{\mathrm{T}}=$ total outside barn width; 1 = feeding area; 2 = free stall front; 3 = free stall side; $4=$ wall of barn.

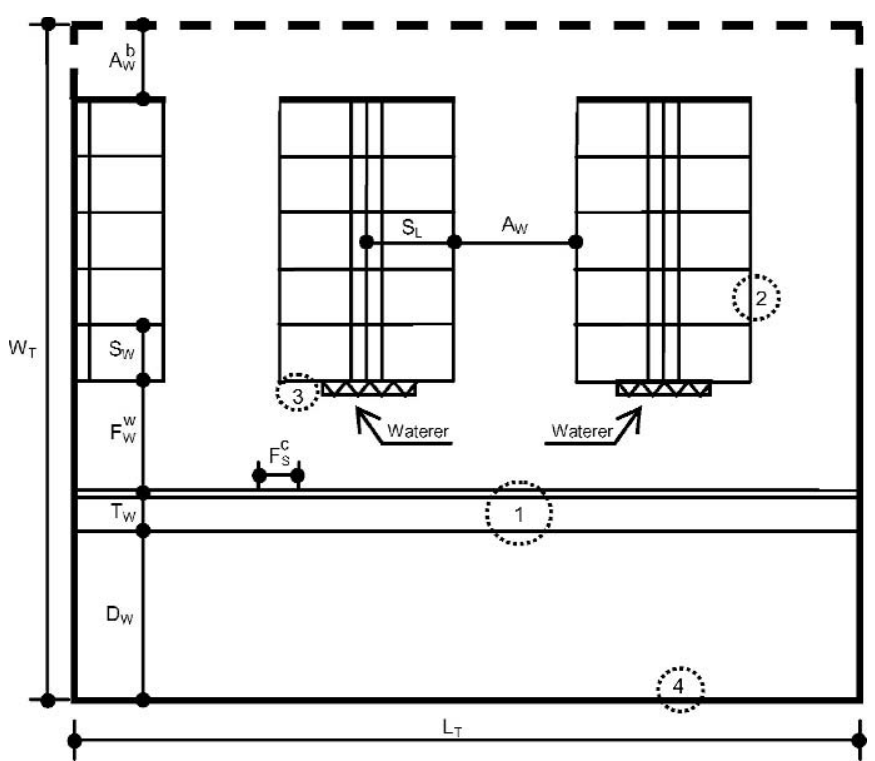

Figure 4. Design with stall rows perpendicular to feed alley: $A_{W}=$ free stall alley width; $D_{\mathrm{W}}=$ driveway width; $\mathrm{F}_{\mathrm{W}}^{\mathrm{W}}=$ feed alley width (with waterers); $F_{S}^{c}=$ feeding space per cow; $L_{T}=$ total outside barn length; $\mathrm{S}_{\mathrm{L}}=$ stall length; $\mathrm{S}_{\mathrm{W}}=$ stall width; $\mathrm{T}_{\mathrm{W}}=$ feeding table width; $\mathrm{W}_{\mathrm{T}}=$ total outside barn width; 1 = feeding area; 2 = free stall front; $3=$ free stall side; $4=$ wall of barn.

Tucker and Weary, 2001; Wagner-Storch et al., 2003). The layout and characteristics of cross alleys are important for resting-area design (Callejo et al., 1997; Bickert et al., 2000). The principal characteristics of the exercise area are as follows: dimensions, floor type, and cleaning system (Vokey et al., 2001; Stefanowska et al., 2002). Also important for design are feeder characteristics and space per cow (Hansen and Pallensen, 1998; DeVries et al., 2004). The number, position, and characteristics of waterers are also important (Anonymous, 2001; Machado et al., 2004). The size, location, and characteristics of the milking zone are also critical for barn layout (Carreira Pérez, 1996; Buxadé Carbó, 2002).

In the second phase of algorithm development, with the aim of establishing final barn dimensions, we established the parameters to be used and the ways in which they would be used. The parameters can be grouped as a function of the stage at which they intervene in the design process. Some parameters used in the design intervene at an early stage, and can be considered basic parameters: herd size, stall dimensions (width, length), maximum number of contiguous stalls, cross alleys (width with and without waterers), and feeding space per cow at the feed barrier. Other parameters intervene at a subsequent stage, namely driveway width, eating surface width, feed alley width, and dimensions of structural columns. 

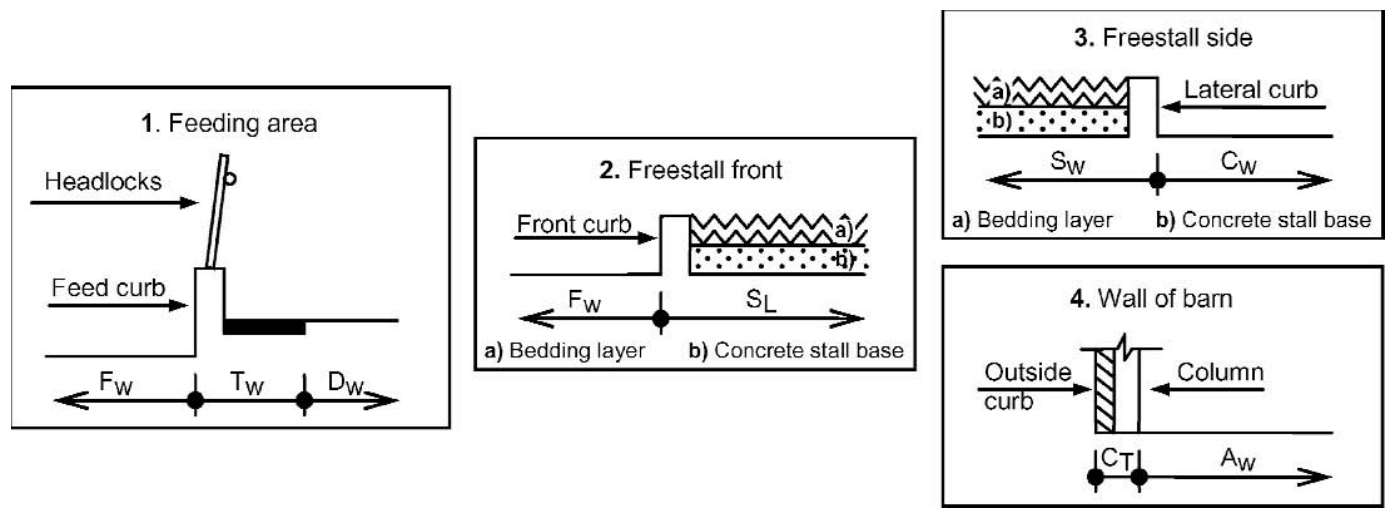

Figure 5. Details of designs: $A_{W}=$ free stall alley width; $C_{T}=$ column thickness; $C_{W}=$ cross alley width (with or without waterers); $D_{W}=$ driveway width; $\mathrm{F}_{\mathrm{W}}=$ feed alley width; $\mathrm{S}_{\mathrm{L}}=$ stall length; $\mathrm{S}_{\mathrm{W}}=$ stall width; $\mathrm{T}_{\mathrm{W}}=$ feeding table width.

The values defining the design parameters (e.g., stall width) are related to the specifics of housed cows (such as body dimensions or weight). These values can be found in an interval, as noted by the authors mentioned above, and they can be considered variable. It is thus the responsibility of the barn designer to select the most appropriate dimensions in each case. Recommendations about the dimensions of the elements of internal distribution are given in Table 1.

In the third phase of algorithm development, the functional areas of study were defined, namely resting area, exercise area, and feeding area, because these 3 areas are closely related, and they constitute the central components of the design as a whole. The dimensional interrelationship of these 3 functional areas will indicate whether it is possible to introduce other areas into the building (such as milking, maternity, or calving areas), areas which, a priori, might be included in other locations in the same housing. This dimensional interrelationship is identified by comparing the resting area and the feeding area, in each case with one of the input parameters being the number of places with respect to total herd size. Some studies have analyzed the possibility of reducing the number of stalls (with respect to total herd size) in either or both of these areas (Carreira Pérez, 1996; Stamer et al., 2000) and the possibility of increasing this number (Menzies and Mackie, 2001).

Thus, an important criterion to be borne in mind is the number of feeding places vs. the number of places available in the resting area (i.e., number of free stalls). If we want to eliminate competition for food, there must be 1 feeding place for each cow. However, current systems for feed management can provide feed ad libitum, thus eliminating competition, so that the criterion of 1 feeding place per cow can be varied by applying a reducing coefficient. Similarly, it could be considered a ratio of cows per free stall of 1:1 or different. To consider these aspects, herd size can be treated as a variable, and the barn designer can apply reducing coefficients. Another possibility of variation of dimensions in the resting or feeding area could be the use of concentrate feeders in these positions (they should be accessed from the feeding area; Anonymous, 2001) that the designer could take into account in the design.

It is also important to consider the maximum number of contiguous stalls (number of stalls in line without a crossover), which should be small enough to avoid "tunnel" effects and reduce the distance that animals must walk.

The calculation procedure varies depending on the internal organization of the stable: stall rows aligned parallel to the feed alley (2 rows head-to-head, or 2 rows head-to-wall, or 3 rows), and stall rows aligned perpendicular to the feed alley.

The next stage (stage 4) was to draw the plans of the barns for the modules proposed, for herd sizes of 10 to 250 cows, with the aim of determining patterns in the variation of the elements of the internal distribution, considering the number of contiguous stalls.

Having identified the key design parameters, we next developed algorithms for generating barn layout and overall size given user input of a) herd size, b) basic barn design (2 rows head-to-head, 2 rows head-to-wall, 3 rows, or rows perpendicular to feed alley), and c) 1 or more basic parameters for each design type (e.g., for the 2-row head-to-head design, maximum number of contiguous stalls).

In the final stage, the design algorithms were developed. The most salient aspects of this development are discussed in detail below.

\section{Two-Row Head-to-Head Designs}

In the calculation procedure for 2-row head-to-head designs (Figure 1), the resting area comprises blocks of 


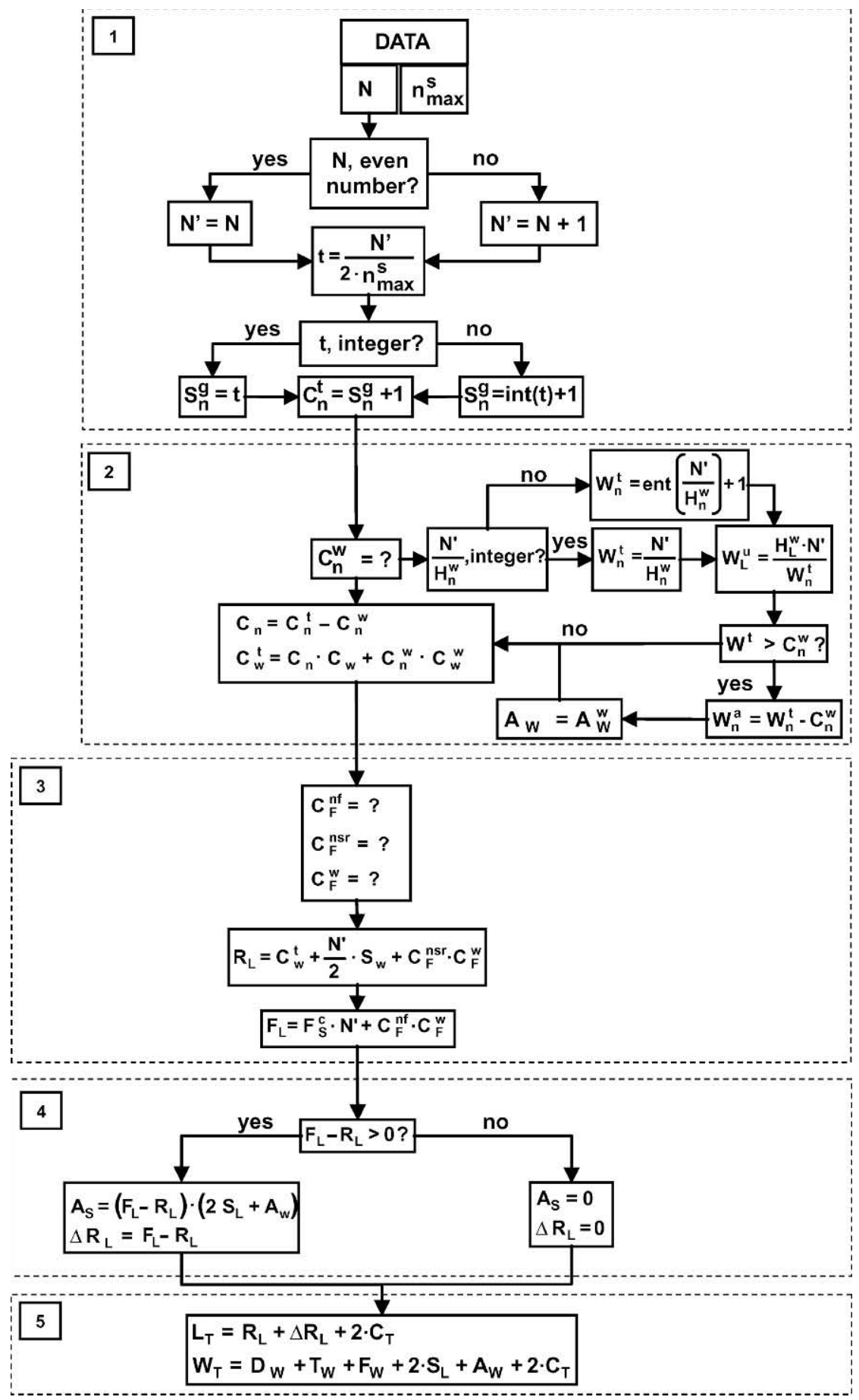

Figure 6. Two-row head-to-head design algorithm: $A_{S}=$ additional space for other areas; $A_{W}=$ free stall alley width (without waterers); $\mathrm{A}_{\mathrm{W}}^{\mathrm{W}}=$ free stall alley width (with waterers); $\mathrm{C}_{\mathrm{n}}=$ cross alley number (without waterers); $\mathrm{C}_{\mathrm{T}}=$ column thickness; $\mathrm{C}_{\mathrm{W}}=$ cross alley width (without waterers); $\mathrm{C}_{\mathrm{F}} \mathrm{nf}=$ concentrate feeder number (placed at the feeding table); $\mathrm{C}_{\mathrm{F}}^{\mathrm{nsr}}=$ concentrate feeder number (placed in stall rows); $\mathrm{C}_{\mathrm{F}}^{\mathrm{W}}=$ concentrate feeder width; $\mathrm{C}_{\mathrm{n}}^{\mathrm{t}}=$ cross alley total number; $\mathrm{C}_{\mathrm{W}}^{\mathrm{t}}=$ cross alley total width; $\mathrm{C}_{\mathrm{n}}^{\mathrm{W}}=$ cross alley number (with waterers); $\mathrm{C}_{\mathrm{W}}^{\mathrm{W}}=$ cross alley width (with waterers); $D_{W}=$ driveway width; $F_{L}$ = feeding area length; $F_{W}=$ feed alley width; $F_{S}^{c}=$ feeding space per cow; $H_{\mathrm{L}}^{\mathrm{w}}=$ waterer length per cow; $\mathrm{H}_{\mathrm{n}}^{\mathrm{w}}=$ number of heads per waterer; $\mathrm{L}_{\mathrm{T}}=$ total outside barn length; $\mathrm{N}=$ herd size; $\mathrm{n}_{\max }^{\mathrm{s}}=$ maximum number of contiguous stalls; $R_{L}=$ resting area length; $S_{L}=$ stall length; $S_{W}=$ stall width; $S_{n}^{g}=$ stall group number; $T_{W}=$ feeding table width; $W_{T}=$ total outside barn width; $\mathrm{W}_{\mathrm{n}}^{\mathrm{a}}=$ number of waterers in alleys; $\mathrm{W}_{\mathrm{n}}^{\mathrm{t}}=$ total number of needed waterers; $\mathrm{W}_{\mathrm{L}}^{\mathrm{u}}=$ minimum length of waterers; $\Delta \mathrm{R}_{\mathrm{L}}=$ increase in resting area length. 


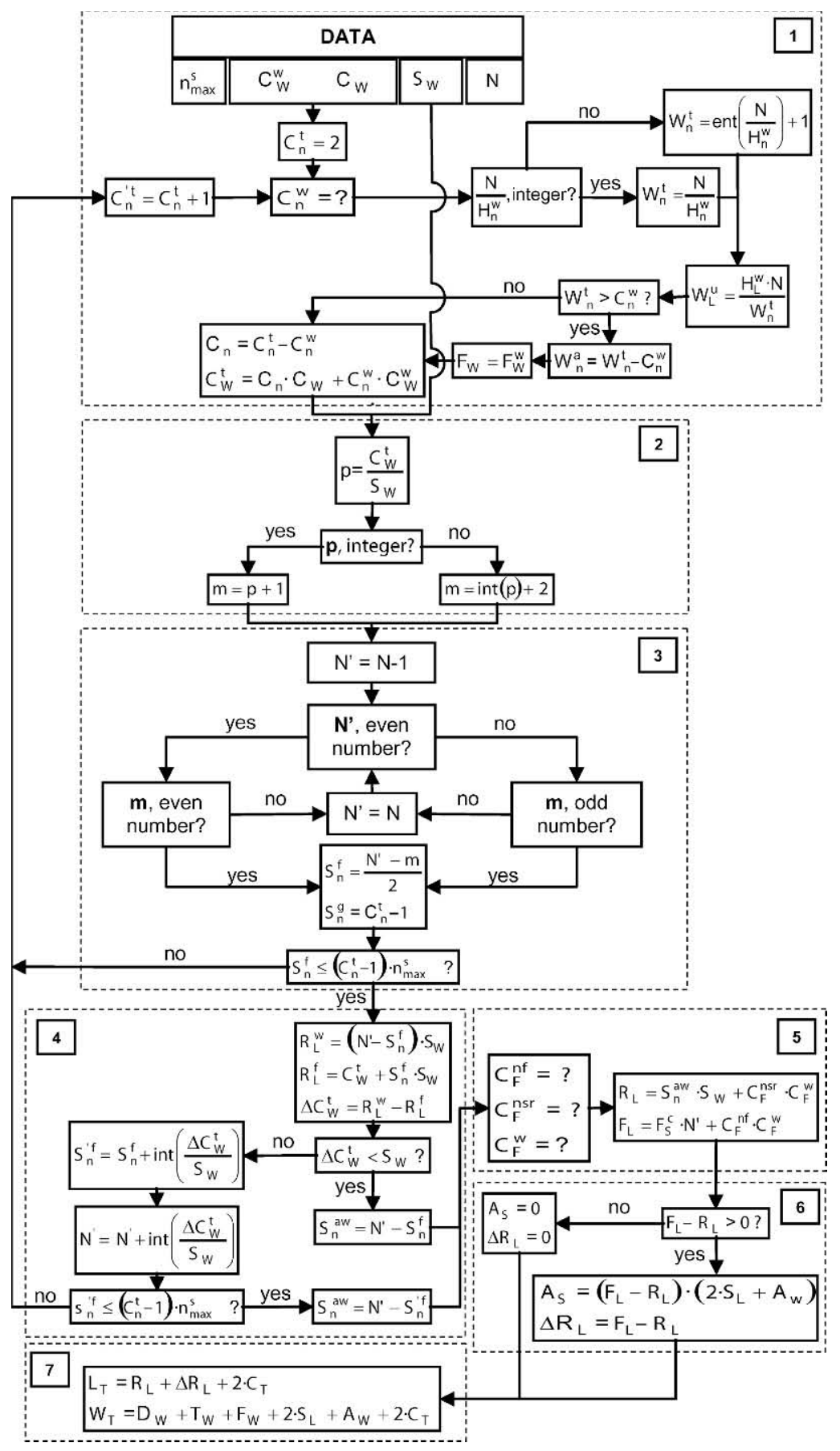

Figure 7. Two-row head-to-wall design algorithm: $A_{S}=$ additional space for other areas; $A_{W}=$ free stall alley width; $C_{n}=$ cross alley number (without waterers); $\mathrm{C}_{\mathrm{T}}=$ column thickness; $\mathrm{C}_{\mathrm{W}}=$ cross alley width (without waterers); $\mathrm{C}_{\mathrm{F}}^{\mathrm{nf}}=$ concentrate feeder number (placed at the feeding table); $\mathrm{C}_{\mathrm{F}}^{\mathrm{nsr}}=$ concentrate feeder number (placed in stall rows); $\mathrm{C}_{\mathrm{F}}^{\mathrm{W}}=$ concentrate feeder width; $\mathrm{C}_{\mathrm{n}}^{\mathrm{t}}=$ cross alley total number; $\mathrm{C}_{\mathrm{W}}^{\mathrm{t}}=$ cross alley total width; $\mathrm{C}_{\mathrm{n}}^{\mathrm{W}}=$ cross alley number (with waterers); $\mathrm{C}_{\mathrm{W}}^{\mathrm{W}}=$ cross alley width (with waterers); $\mathrm{D}_{\mathrm{W}}=$ driveway width; $\mathrm{F}_{\mathrm{L}}=$ feeding area length; $\mathrm{F}_{\mathrm{W}}=$ feed alley width (without waterers); $\mathrm{F}_{\mathrm{W}}^{\mathrm{W}}=$ feed alley width (with waterers); $\mathrm{F}_{\mathrm{S}}^{\mathrm{c}}=$ feeding space per cow; $\mathrm{H}_{\mathrm{L}}^{\mathrm{W}}=$ waterer length per cow; $\mathrm{H}_{\mathrm{n}}^{\mathrm{w}}=$ number of heads per waterer; $\mathrm{L}_{\mathrm{T}}=$ total outside barn length; $\mathrm{N}=$ herd size; $\mathrm{n}_{\max }^{\mathrm{s}}=$ maximum number of contiguous stalls; $R_{\mathrm{L}}=$ resting area length; $\mathrm{R}_{\mathrm{L}}^{\mathrm{f}}=$ resting area length (front-row stalls); $\mathrm{R}_{\mathrm{L}}^{\mathrm{w}}=$ resting area length (stalls against the wall); $\mathrm{S}_{\mathrm{L}}=$ stall length; $\mathrm{S}_{\mathrm{W}}=$ stall width; $\mathrm{S}_{\mathrm{n}}^{\mathrm{aw}}=$ number of stalls against the wall; $\mathrm{S}_{\mathrm{n}}^{\mathrm{f}}=$ number of stalls in front row; $\mathrm{S}_{\mathrm{n}}^{\mathrm{g}}=$ stall group number; $\mathrm{T}_{\mathrm{W}}=$ feeding table width; $\mathrm{W}_{\mathrm{T}}=$ total outside barn width; $\mathrm{W}_{\mathrm{n}}^{\mathrm{a}}=$ number of waterers in alleys; $\mathrm{W}_{\mathrm{n}}^{\mathrm{t}}=$ total number of needed waterers; $\mathrm{W}_{\mathrm{L}}^{\mathrm{u}}=$ minimum length of waterers; $\Delta \mathrm{C}_{\mathrm{W}}^{\mathrm{t}}=$ increase in cross alley total width; $\Delta \mathrm{R}_{\mathrm{L}}=$ increase in resting area length. 


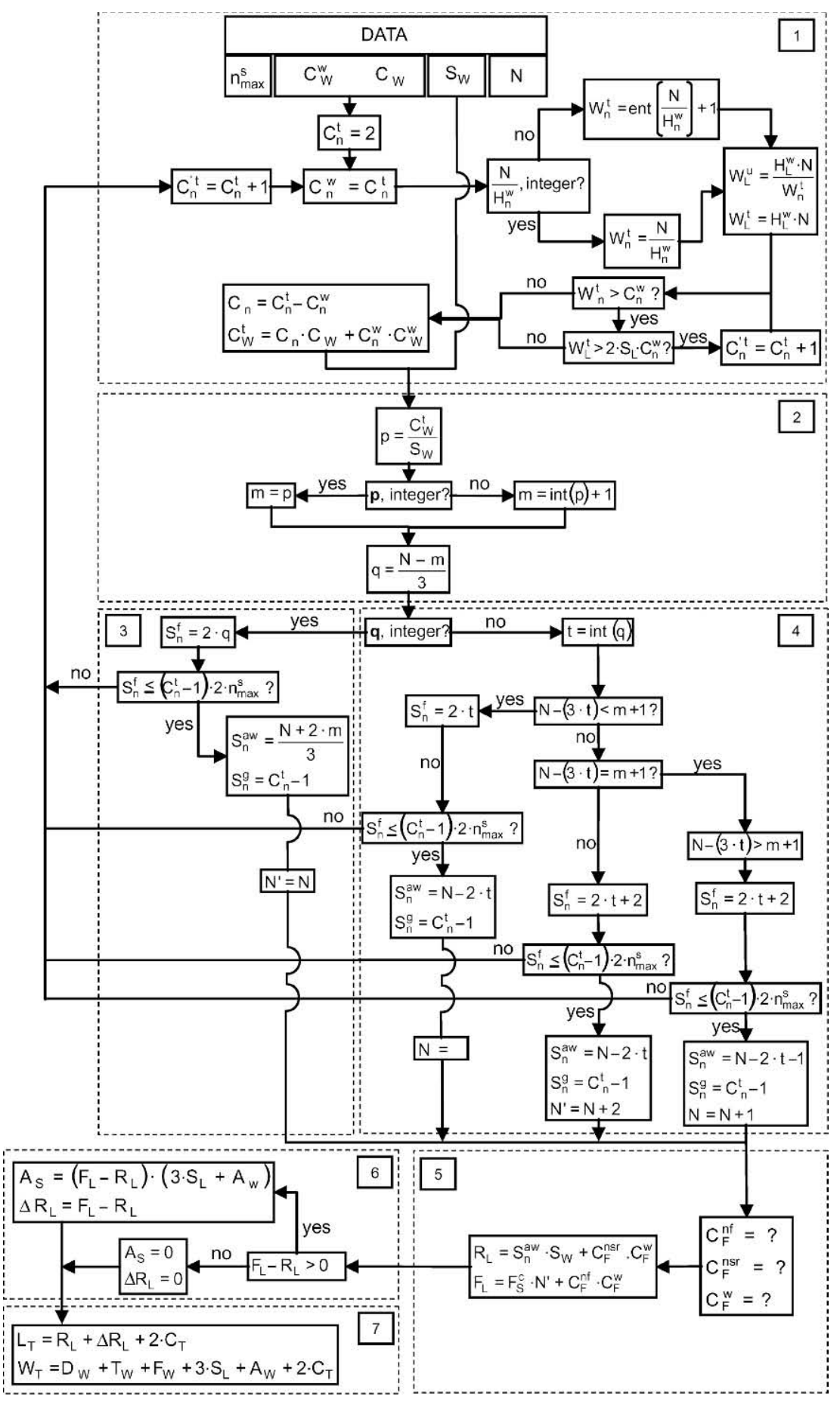

Figure 8. Three-row design algorithm: $A_{S}=$ additional space for other areas; $A_{W}=$ free stall alley width; $C_{n}=$ cross alley number (without waterers); $\mathrm{C}_{\mathrm{T}}=$ column thickness; $\mathrm{C}_{\mathrm{W}}=$ cross alley width (without waterers); $\mathrm{C}_{\mathrm{F}}^{\mathrm{nf}}=$ concentrate feeder number (placed at the feeding table); $\mathrm{C}_{\mathrm{F}}^{\mathrm{nsr}}=$ concentrate feeder number (placed in stall rows); $\mathrm{C}_{\mathrm{F}}^{\mathrm{w}}=$ concentrate feeder width. $\mathrm{C}_{\mathrm{n}}^{\mathrm{t}}=$ cross alley total number; $\mathrm{C}_{\mathrm{W}}^{\mathrm{t}}=$ cross alley total width; $\mathrm{C}_{\mathrm{n}}^{\mathrm{w}}=$ cross alley number (with waterers); $\mathrm{C}_{\mathrm{W}}^{\mathrm{W}}=$ cross alley width (with waterers); $\mathrm{D}_{\mathrm{W}}=$ driveway width; $\mathrm{F}_{\mathrm{L}}=$ feeding area length; $\mathrm{F}_{\mathrm{W}}=$ feed alley width; $\mathrm{F}_{\mathrm{S}}^{\mathrm{c}}=$ feeding space per cow; $\mathrm{H}_{\mathrm{L}}^{\mathrm{W}}=$ waterer length per cow; $\mathrm{H}_{\mathrm{n}}^{\mathrm{w}}=$ number of heads per waterer; $\mathrm{L}_{\mathrm{T}}=$ total outside barn length; $\mathrm{N}=$ herd size; $\mathrm{n}_{\max }^{\mathrm{s}}=$ maximum number of contiguous stalls; $\mathrm{R}_{\mathrm{L}}=$ resting area length; $\mathrm{S}_{\mathrm{L}}=$ stall length; $\mathrm{S}_{\mathrm{W}}=$ stall width; $\mathrm{S}_{\mathrm{n}}^{\text {aw }}=$ number of stalls against the wall; $\mathrm{S}_{\mathrm{n}}^{\mathrm{f}}=$ number of stalls in front row; $\mathrm{S}_{\mathrm{n}}^{\mathrm{g}}=$ stall group number; $\mathrm{T}_{\mathrm{W}}=$ feeding table width; $\mathrm{W}_{\mathrm{T}}=$ total outside barn width; $\mathrm{W}_{\mathrm{n}}^{\mathrm{a}}=$ number of waterers in alleys; $\mathrm{W}_{\mathrm{n}}^{\mathrm{t}}=$ total number of needed waterers; $\mathrm{W}_{\mathrm{L}}^{\mathrm{t}}=$ total length of needed waterers; $\mathrm{W}_{\mathrm{L}}^{\mathrm{u}}=$ minimum length of waterers; $\Delta \mathrm{R}_{\mathrm{L}}=$ increase in resting area length. 


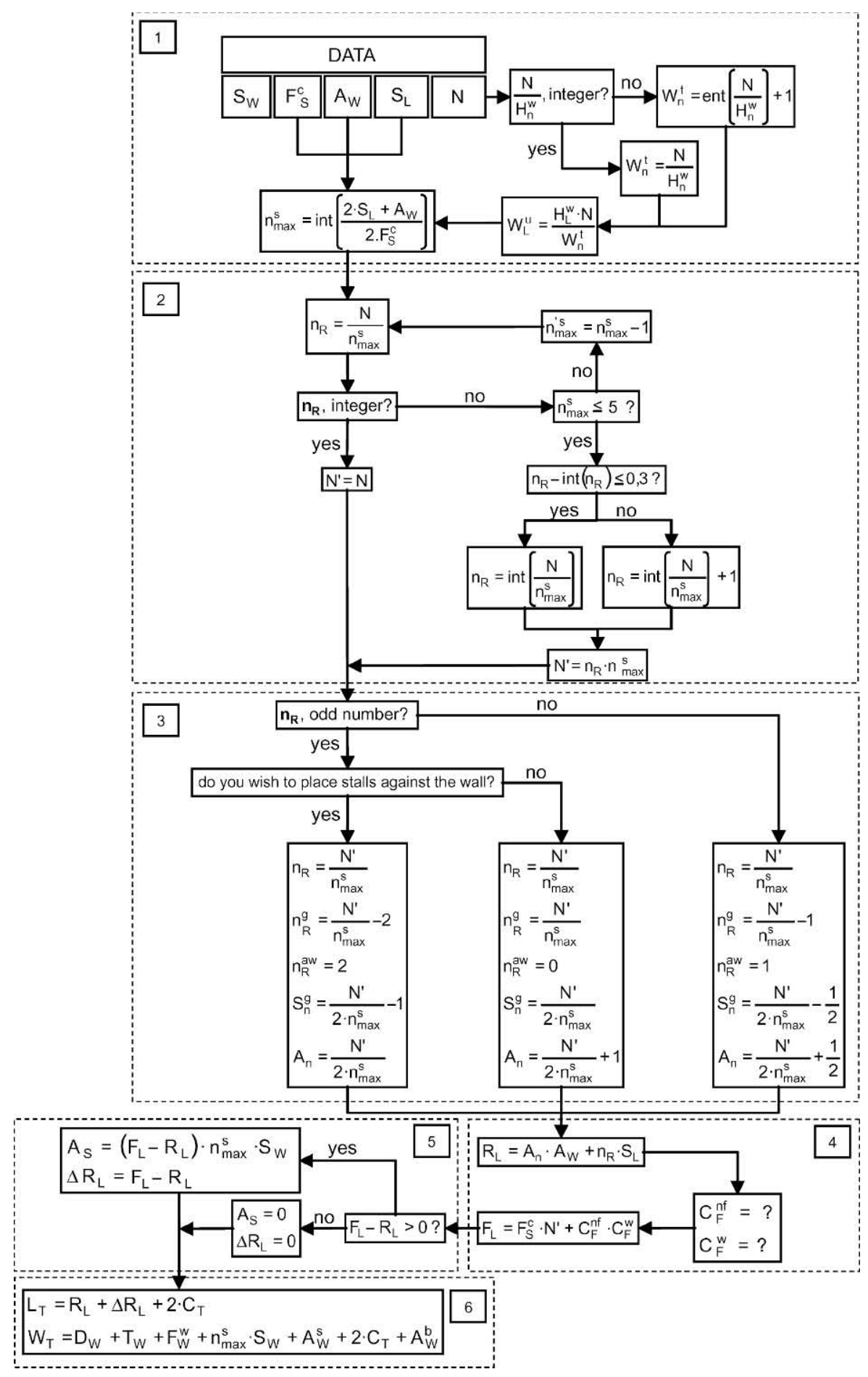

Figure 9. Algorithm for design with stall rows perpendicular to feed alley: $A_{N}=$ free stall alley number; $A_{S}=$ additional space for other areas; $A_{W}=$ free stall alley width; $A_{W}^{b}=$ alley width (placed at the back of the barn); $\mathrm{C}_{\mathrm{T}}=$ column thickness; $\mathrm{C}_{\mathrm{F}}^{\mathrm{nf}}=$ concentrate feeder number (placed at the feeding table); $\mathrm{C}_{\mathrm{F}}^{\mathrm{nsr}}=$ concentrate feeder number (placed in stall rows); $\mathrm{C}_{\mathrm{F}}^{\mathrm{W}}=$ concentrate feeder width; $\mathrm{D}_{\mathrm{W}}=\mathrm{driveway}$ width; $\mathrm{F}_{\mathrm{L}}=$ feeding area length; $\mathrm{F}_{\mathrm{W}}^{\mathrm{W}}=$ feed alley width (with waterers); $\mathrm{F}_{\mathrm{S}}^{\mathrm{c}}=$ feeding space per cow; $\mathrm{H}_{\mathrm{L}}^{\mathrm{w}}=$ waterer length per cow; $\mathrm{H}_{\mathrm{n}}^{\mathrm{w}}=$ number of heads per waterer; $\mathrm{L}_{\mathrm{T}}=$ total outside barn length; $\mathrm{N}=$ herd size; $\mathrm{n}_{\mathrm{R}}=$ total number of stall rows; $\mathrm{n}_{\mathrm{R}}^{\text {aw }}=$ number of stall rows against the wall; $\mathrm{n}_{\mathrm{R}}^{\mathrm{g}}=$ number of free-standing rows; $\mathrm{n}_{\max }^{\mathrm{s}}=$ maximum number of contiguous stalls; $\mathrm{R}_{\mathrm{L}}=$ resting area length; $\mathrm{S}_{\mathrm{L}}=$ stall length; $\mathrm{S}_{\mathrm{W}}=$ stall width; $\mathrm{S}_{\mathrm{n}}^{\mathrm{g}}=$ stall group number; $\mathrm{T}_{\mathrm{W}}=$ feeding table width; $\mathrm{W}_{\mathrm{T}}=$ total outside barn width; $\mathrm{W}_{\mathrm{n}}^{\mathrm{t}}=$ total number of needed waterers; $\mathrm{W}_{\mathrm{L}}^{\mathrm{u}}=$ minimum length of waterers; $\Delta \mathrm{R}_{\mathrm{L}}=$ increase in resting area length. 
Table 2. Results for both options of the 2-row head-to-head design

\begin{tabular}{|c|c|c|c|}
\hline \multirow[b]{2}{*}{ Description and abbreviation } & & Option A & \multirow{2}{*}{$\begin{array}{l}\text { Option B } \\
\text { Cross alleys } \\
\text { with waterers }\end{array}$} \\
\hline & & $\begin{array}{l}\text { Cross alleys } \\
\text { without waterers }\end{array}$ & \\
\hline No. of cows (initial) & $\mathrm{N}$ & 75 & 75 \\
\hline No. of cows (final) & $\mathrm{N}^{\prime}$ & 76 & 76 \\
\hline Stall group number & $\mathrm{S}_{\mathrm{n}}^{\mathrm{g}}$ & 2 & 2 \\
\hline Cross alley total number & $\mathrm{C}_{\mathrm{n}}^{\mathrm{t}}$ & 3 & 3 \\
\hline Cross alley number (without waterer) & $\mathrm{C}_{\mathrm{n}}$ & 3 & 0 \\
\hline Cross alley number (with waterer) & $\mathrm{C}_{\mathrm{n}}^{\mathrm{W}}$ & 0 & 3 \\
\hline Cross alley total width, $\mathrm{m}$ & $\mathrm{C}_{\mathrm{w}}^{\mathrm{t}}$ & 7.95 & 11.25 \\
\hline No. of waterers in free stall alley & $\mathrm{W}_{\mathrm{n}}^{\mathrm{a}}$ & 4 & 1 \\
\hline Resting area length, m & $\mathrm{R}_{\mathrm{L}}$ & 53.55 & 56.85 \\
\hline Feeding area length, $\mathrm{m}$ & $\mathrm{F}_{\mathrm{L}}$ & 57.00 & 57.00 \\
\hline Increase in resting area length, $\mathrm{m}$ & $\Delta \mathrm{R}_{\mathrm{L}}$ & 3.45 & 0.15 \\
\hline Additional space for other areas, $\mathrm{m}^{2}$ & $\mathrm{~A}_{\mathrm{S}}$ & 31.05 & 1.35 \\
\hline Total outside barn length, m & $\mathrm{L}_{\mathrm{T}}$ & 57.60 & 57.60 \\
\hline Total outside barn width, m & $\mathrm{W}_{\mathrm{T}}$ & 19.10 & 19.10 \\
\hline
\end{tabular}

stalls separated by cross alleys. The number of blocks formed will be a function of the maximum number of contiguous stalls considered. Thus, we suggest a calculation procedure that allows determination of the number of blocks of stalls and cross alleys located between them. The final length will be directly related to these parameters, and to whether waterers are present in the cross alleys (in this case, waterers could be placed on the wall of the back free-stall alley). The required input parameters for this calculation are herd size $(N)$ and maximum number of stalls per row $\left(n_{\max }\right)$.

\section{Two-Row Head-to-Wall Designs}

The starting point for the design of this distribution is that the back row should be fully occupied by stalls (Figure 2). In the front row, the space is divided into 2 zones: 1 zone occupied by stalls, and the other by cross alleys (for access to the feeding area and to stalls). By determining the number of stalls in the back row that occupy the same space as that dedicated to the alley in the front row, the design is immediate, giving the number of stalls in the front row. This is achieved by definition of the parameter $p$, which relates total cross alley width to stall width. Based on this relation, the distribution of free stalls between back and front rows is done.

In the calculation procedure for 2-row head-to-wall designs, the required input parameters are herd size $(N)$, cross alley total width $\left(C_{W}^{t}\right)$, with waterer $\left(C_{W}^{w}\right)$ and without waterer $\left(C_{W}\right)$, stall width $\left(S_{W}\right)$.

\section{Three-Row Designs}

In 3-row designs (Figure 3), the resting area comprises a continuous row of head-to-wall stalls, or various head-to-head blocks, with a user-defined maximum number of stalls per block (i.e., maximum number of contiguous stalls). As in the 2-row head-to-wall design, the number of blocks required is a function of the maximum acceptable number of contiguous stalls, and of the dimensions of the internal elements (i.e., of stalls and cross alleys). The final length of the resting area will depend on internal distribution; that is, the number of head-to-wall stalls giving the required number of blocks (in line with space requirements) and the required number of cross alleys. The internal organization of the elements of the resting area is not known a priori, because it will vary as function of the dimensions of these elements. Again, the parameter $m$ is calculated, allowing definition of the number of stalls in the back row, and thus in the front 2 rows. This parameter is based on the relation between total cross alley width and stall width and it is used for the distribution of the free stalls in the rows.

In the calculation procedure for 3-row designs, the required input parameters are herd size $(N)$, cross alley width (with waterer $C_{W}^{w}$ or without waterer $C_{W}$ ), stall width $\left(S_{W}\right)$, and maximum number of contiguous stalls $\left(n_{\text {max }}^{s}\right)$.

\section{Designs with Stall Rows Perpendicular to Feed Alley}

In designs in which the stalls are organized in several groups of 2 parallel head-to-head rows perpendicular to the feed alley (Figure 4), the resting area comprises several transverse blocks. The number of blocks will depend on 2 aspects of internal distribution: stall width and maximum acceptable number of contiguous stalls. The cross alleys serve only to access the resting stalls, 


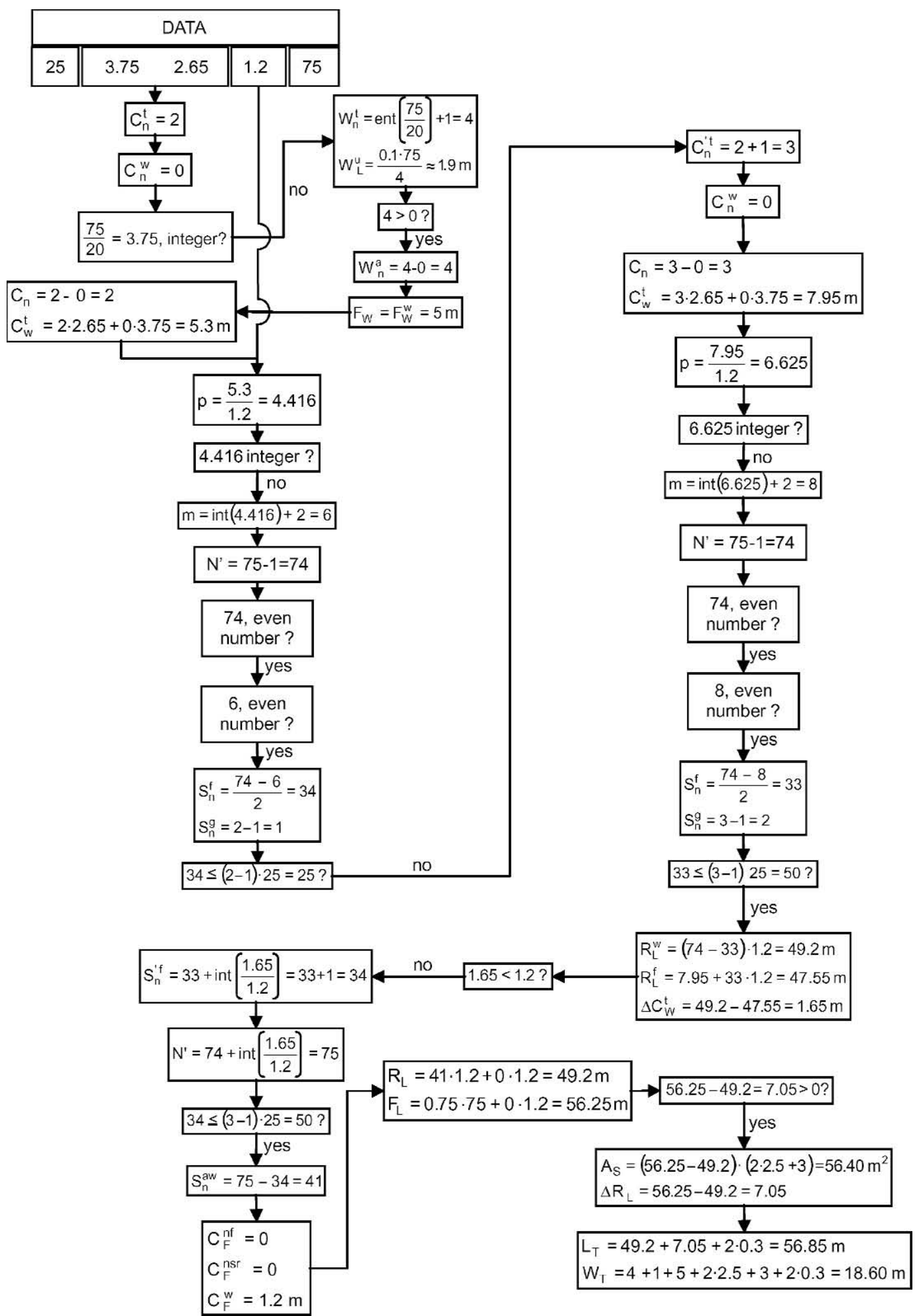

Figure 10. Working of the 2-row head-to-wall design algorithm (option A in Table 3). 
Table 3. Results for all options of the 2-row head-to-wall design

\begin{tabular}{llcrcr}
\hline & & \multicolumn{4}{c}{ Option $^{1}$} \\
\cline { 3 - 6 } Description and abbreviation & & $\mathrm{A}$ & $\mathrm{B}$ & $\mathrm{C}$ & $\mathrm{D}$ \\
\hline No. of cows (initial) & $\mathrm{N}$ & 75 & 75 & 75 & 75 \\
Cross alley total number & $\mathrm{C}_{\mathrm{n}}^{\mathrm{t}}$ & 3 & 3 & 3 & 3 \\
Cross alley number (with waterer) & $\mathrm{C}_{\mathrm{n}}^{\mathrm{w}}$ & 0 & 1 & 2 & 3 \\
Cross alley number (without waterer) & $\mathrm{C}_{\mathrm{n}}$ & 3 & 2 & 1 & 0 \\
Cross alley total width, m & $\mathrm{C}_{\mathrm{w}}^{\mathrm{t}}$ & 7.95 & 9.05 & 10.15 & 11.25 \\
No. of waterers in free stall alley & $\mathrm{W}_{\mathrm{n}}^{\mathrm{a}}$ & 4 & 3 & 2 & 1 \\
No. of cows (final) & $\mathrm{N}^{\prime}$ & 75 & 76 & 75 & 76 \\
No. of stalls in front row & $\mathrm{S}_{\mathrm{n}}^{\mathrm{f}}$ & 34 & 34 & 33 & 33 \\
Stall group number & $\mathrm{S}_{\mathrm{n}}^{\mathrm{g}}$ & 2 & 2 & 2 & 2 \\
No. of stalls against the wall & $\mathrm{S}_{\mathrm{n}}^{\mathrm{aw}}$ & 41 & 42 & 42 & 43 \\
Resting area length (stalls against the wall), $\mathrm{m}$ & $\mathrm{R}_{\mathrm{L}}^{\mathrm{w}}$ & 49.20 & 50.40 & 50.40 & 51.60 \\
Resting area length (front-row stalls), $\mathrm{m}$ & $\mathrm{R}_{\mathrm{L}}^{\mathrm{f}}$ & 48.75 & 49.85 & 49.75 & 50.85 \\
Increase in cross alley width, m & $\mathrm{C}_{\mathrm{w}}^{\mathrm{t}}$ & 0.45 & 0.55 & 0.65 & 0.75 \\
Resting area length, m & $\mathrm{R}_{\mathrm{L}}$ & 49.20 & 50.40 & 50.40 & 51.60 \\
Feeding area length, m & $\mathrm{F}_{\mathrm{L}}$ & 56.25 & 57.00 & 56.25 & 57.00 \\
Increase in resting area length, m & $\Delta \mathrm{R}_{\mathrm{L}}$ & 7.05 & 6.60 & 5.85 & 5.40 \\
Additional space for other areas, m ${ }^{2}$ & $\mathrm{~A}_{\mathrm{S}}$ & 56.40 & 52.80 & 46.80 & 43.20 \\
Total outside barn length, m & $\mathrm{L}_{\mathrm{T}}$ & 56.85 & 57.60 & 56.85 & 57.60 \\
Total outside barn width, m & $\mathrm{W}_{\mathrm{T}}$ & 18.60 & 18.60 & 18.60 & 18.60 \\
\hline
\end{tabular}

\footnotetext{
${ }^{1}$ Option $\mathrm{A}=$ all cross alleys without waterers; $\mathrm{B}=$ one cross alley with waterer; $\mathrm{C}=$ two cross alleys with
} waterers; $\mathrm{D}=$ all cross alleys with waterers.

and will not influence internal distribution (in contrast with the other designs). Cross-alley dimensions will affect the final length of the resting area; however, because it is not possible to place waterers in the cross alleys, the range of possible cross-alley widths that must be taken into account is smaller. Final length will depend on the number of transverse rows, stall length, and number and dimensions of the alleys.

Important disadvantages of this design include cow welfare because a boss cow can control the movement of timid cows and manure management may be more difficult (Adams et al., 1995). Some solutions could minimize these problems; such as eliminating the wall at the end of the stall alley (access to an alley or to an open exercise yard) and employing slatted floors or alley flush for cleaning. Considering all these aspects, this design could be an option in some particular cases.

In the calculation procedure for these designs, the required input parameters are herd size $(N)$, stall width $\left(S_{W}\right)$, stall length $\left(S_{L}\right)$, feeding space per cow $\left(F_{S}^{c}\right)$, and free-stall alley width $\left(A_{w}\right)$.

Some details corresponding to previous figures are shown in Figure 5.

\section{RESULTS AND DISCUSSION}

Using design considerations outlined in the previous section, we performed extensive trials aimed at developing algorithms that gave appropriate design solutions under a wide range of starting conditions. Having identified appropriate algorithms, we then simplified them to facilitate rapid computer implementation. The eventual aim is to use these algorithms in a computer program designed for use by farmers. A computer program of this type can be used to identify optimal designs for a given herd size, and to evaluate the advantages and disadvantages of each design. Note that our present algorithms consider only the resting and feeding areas; the completed program will additionally have to consider other areas for milking, exercise, maternity, and storage. In what follows, we present the algorithms obtained in this way for each type of design.

The algorithm for 2-row head-to-head designs (Figure 6) first obtains the number of blocks of stalls and the number of alleys between them. To obtain the number of stalls per row it is necessary simply to divide herd size by 2 if herd size is even; or round up or down if herd size is odd (part 1 in Figure 6). Then, the number and position (in crossovers or in back free-stall alley) of needed waterers are considered (Figure 6, part 2). Given the position of waterers, the alley width has to be defined. After this, the situation of concentrate feeders is taken into account (in stall line or feeding line), increasing length in resting area or feeding area (part 3 ). The algorithm then calculates the final dimensions of the barn based on these parameters (parts 4 and 5 in Figure 6).

The algorithm for 2-row head-to-wall designs (Figure 7) starts by calculating the number of stalls in the front and back rows, the number of cross alleys required, and 

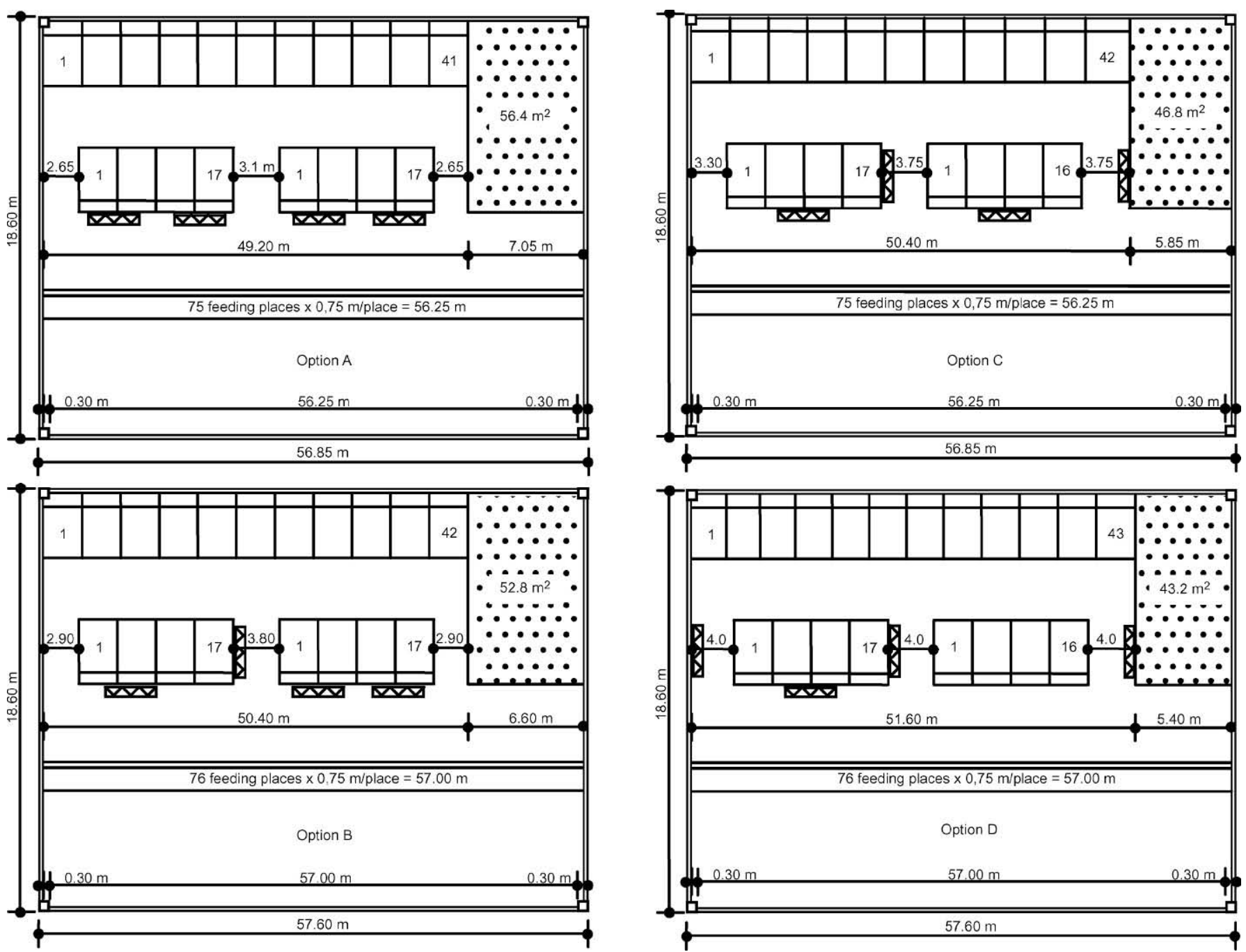

Figure 11. Distribution layouts for the example of the 2-row head-to-wall design (Table 3).

the number of blocks of stalls in the front row. The dimensions of the resting area are calculated based on these parameters. In this case, firstly, the number of considered crossovers is 2 and the number and position of waterers is defined (part 1 in Figure 7). Once the location of waterers is determined, the feed alley width has to be defined. Then, the number of free stalls in the back row that occupies the same space as that dedicated to the crossovers in the front row is determined (part 2). The number of free stalls in the back row and in the front row is defined (part 3). If the number of free stalls in the front row is bigger than the maximum number of free stalls without a crossover (defined in part 1), another crossover is needed (and it is necessary repeat from part 1 in the algorithm; Figure 7). If the number of free stalls in the front row is lower than the maximum number of free stalls without a crossover, we compared the length of the back row and the length of the front row plus the width of crossovers; if the difference was bigger than 1 stall width, another stall was considered (part 4). Then, we considered the presence of concentrate feeders (part 5) and finally the dimensions of barn are calculated (part 6 and 7 in Figure 7).

The algorithm for 3-row designs (Figure 8) first calculates internal-distribution parameters: number of stalls in the front row, number of stalls in the back row, number of blocks of stalls, and number of alleys between them. Based on these parameters, total barn dimensions are then calculated. In this case, firstly, the number of considered crossovers is 2 with waterers included. Once the needed length for waterers is known, the number of cross alleys needed to place them is fixed (part 1 in Figure 8). After that, the number of free stalls in 
Table 4. Results for the 3-row design

\begin{tabular}{llc}
\hline & & $\begin{array}{l}\text { All cross } \\
\text { alleys with } \\
\text { waterers }\end{array}$ \\
\hline Noscription and abbreviation & $\mathrm{N}$ & 75 \\
Cross alley total number & $\mathrm{C}_{\mathrm{n}}^{\mathrm{t}}$ & 2 \\
Cross alley number (with waterer) & $\mathrm{C}_{\mathrm{n}}^{\mathrm{w}}$ & 2 \\
Cross alley number (without waterer) & $\mathrm{C}_{\mathrm{n}}$ & 0 \\
Cross alley total width, m & $\mathrm{C}_{\mathrm{w}}^{\mathrm{t}}$ & 7.50 \\
No. of stalls in front row & $\mathrm{S}_{\mathrm{n}}^{\mathrm{f}}$ & 46 \\
Stall group number & $\mathrm{S}_{\mathrm{n}}^{\mathrm{g}}$ & 1 \\
No. of stalls against the wall & $\mathrm{S}_{\mathrm{n}}^{\mathrm{aw}}$ & 30 \\
No. of cows (final) & $\mathrm{N}^{\prime}$ & 76 \\
Resting area length (stalls against the wall), $\mathrm{m}$ & $\mathrm{R}_{\mathrm{L}}^{\mathrm{w}}$ & 36.00 \\
Resting area length (front-row stalls), $\mathrm{m}$ & $\mathrm{R}_{\mathrm{L}}^{\mathrm{f}}$ & 35.10 \\
Increase in cross alley width, m & $\Delta \mathrm{C}_{\mathrm{w}}^{\mathrm{t}}$ & 0.90 \\
Resting area length, m & $\mathrm{R}_{\mathrm{L}}$ & 36.00 \\
Feeding area length, m & $\mathrm{F}_{\mathrm{L}}$ & 57.00 \\
Increase in resting area length, m & $\Delta_{\mathrm{R}}$ & 21.00 \\
Additional space for other areas, m ${ }^{2}$ & $\mathrm{~A}_{\mathrm{S}}$ & 220.50 \\
Total outside barn length, m & $\mathrm{L}_{\mathrm{T}}$ & 57.60 \\
Total outside barn width, m & $\mathrm{W}_{\mathrm{T}}$ & 20.60 \\
\hline
\end{tabular}

the back row will equal those that occupy space equal to that dedicated to crossovers in the front rows plus the number of free stalls corresponding to each front row (part 2). If the number of free stalls per row is an integer, we verified that in the front rows, this number is lower than the maximum allowed (part 3); if it does not, another crossover is needed. If the number of free stalls per row is not an integer, another free stall is added in the back row or another 2 added in the front rows, according to available space, and we verify that the number of contiguous free stalls is lower than the maximum number allowed (part 4). After that, the presence of automatic feeders is considered (part 5). Finally, the dimensions of the barn are calculated (parts 6 and 7 in Figure 8).

The algorithm for designs with stall rows perpendicular to feed alley (Figure 9) first calculates total number of rows, numbers of rows in blocks of head-to-head rows, number of rows against the wall, number of blocks, and

Table 5. Results for the perpendicular row design

\begin{tabular}{llc}
\hline Description and abbreviation & & Option A \\
\hline No. of cows (initial) & $\mathrm{N}$ & 75 \\
Total number of stall rows & $\mathrm{n}_{\mathrm{R}}$ & 15 \\
No. of free-standing rows & $\mathrm{n}_{\mathrm{R}}^{\mathrm{g}}$ & 14 \\
No. of rows against the wall & $\mathrm{n}_{\mathrm{R}}^{\mathrm{aw}}$ & 1 \\
Stall group number & $\mathrm{S}_{\mathrm{n}}^{\mathrm{g}}$ & 7 \\
Free stall alley number & $\mathrm{A}_{\mathrm{n}}$ & 8 \\
Resting area length, m & $\mathrm{R}_{\mathrm{L}}$ & 61.50 \\
Feeding area length, m & $\mathrm{F}_{\mathrm{L}}$ & 56.25 \\
Total outside barn length, m & $\mathrm{L}_{\mathrm{T}}$ & 62.10 \\
Total outside barn width, m & $\mathrm{W}_{\mathrm{T}}$ & 17.10 \\
\hline
\end{tabular}

number of cross alleys. Based on these parameters, total barn dimensions are then calculated. In this case, the maximum number of contiguous free stalls is calculated, considering that we can place the same number of cows at the feed barrier as the number of free stalls in the rows considered. We determined the number of waterers positioned only in the feeding alley (part 1 in Figure 9). Then, the needed number of rows is calculated (part 2). After that, it is determined if there are 1 or 2 rows head-to-wall at the end of the barn (part 3 ). The length of the feeding and resting area, accounting for presence of concentrate feeders, is calculated (part 4). The final dimensions of the barn are then determined (part 5 and 6 in Figure 9). However, it is important to bear in mind the disadvantages of this design cited earlier.

These algorithms allow exploration of the effects of diverse variables on optimal stable design, but at the same time constitute a powerful tool for a priori analysis of different management solutions for a given herd size, as a function of the range of values that can be taken by stall dimensions and feeding space per cow.

By way of example, we show the results obtained with these algorithms considering the following examples of starting parameter values: herd size $=75$, free stalls per cow $=1$, feeding places per cow $=1$, width of cross alleys without waterers $=2.65 \mathrm{~m}$, width of cross alleys with waterers $=3.75 \mathrm{~m}$, maximum number of contiguous stalls $=25$, stall width $=1.20 \mathrm{~m}$, stall length $=2.50$ $\mathrm{m}$, space per cow in the feeder $=0.75 \mathrm{~m}, 1$ waterer per group of 20 cows, and without concentrate feeders. The other parameters necessary for defining final dimensions are driveway width $(4.00 \mathrm{~m})$; feeding surface width $(1.00 \mathrm{~m})$; feed alley width with waterers $(5.00$ $\mathrm{m}$ ); feed alley width without waterers for feed alley and cow movement only $(4.00 \mathrm{~m})$, or for feed alley, movement, and access to stalls $(4.50 \mathrm{~m})$; free stall alley width behind or between free stall rows without waterers $(3.00 \mathrm{~m})$, or with waterers $(4.00 \mathrm{~m})$; and column width $(0.30 \mathrm{~m})$.

With the distribution of 2-row head-to-head we studied 2 options (Table 2), considering that all feeding places are available. In option A, with cross alleys without waterers, some extra space is left over. This space can be used for other areas, such as maternity or part of holding area. Option B, in which the cross alleys have waterers, is that which best matches total resting area length and total feeding area length. In both options, it is also necessary to place waterers in the back stall alley, so the width of this alley has to be adequate.

Figure 10 illustrates the algorithm corresponding to the 2-row head-to-wall distribution (option A in Table $3)$. 
Table 6. Comparison of final designs when there are waterers in all cross alleys

\begin{tabular}{|c|c|c|c|c|}
\hline \multirow[b]{2}{*}{ Characteristic } & \multicolumn{4}{|c|}{ Design } \\
\hline & $\begin{array}{l}\text { Two-row } \\
\text { head-to-head }\end{array}$ & $\begin{array}{l}\text { Two-row } \\
\text { head-to-wall }\end{array}$ & Three-row & $\begin{array}{l}\text { Perpendicular } \\
\text { rows }^{1}\end{array}$ \\
\hline No. of cows (initial) & 75 & 75 & 75 & 75 \\
\hline No. of cows (final) & 76 & 76 & 76 & 75 \\
\hline Total outside barn length, $\mathrm{m}$ & 57.60 & 57.60 & 57.60 & 62.10 \\
\hline Total outside barn width, m & 19.10 & 18.60 & 20.60 & $17.10^{2}$ \\
\hline Total built surface, $\mathrm{m}^{2}$ & $1,100.16$ & $1,071.36$ & $1,186.56$ & $1,061.91$ \\
\hline Stall group number & 2 & $2^{3}$ & 1 & 7 \\
\hline Cross alley total number & 3 & 3 & 2 & - \\
\hline Cross alley total width, m & 11.25 & 12 & 8.40 & - \\
\hline No. of waterers in cross alleys & 3 & 3 & 2 & - \\
\hline No. of needed waterers ${ }^{4}$ & 4 & 4 & 4 & 4 \\
\hline No. of waterers in feed alley & 0 & 1 & 0 & 4 \\
\hline No. of waterers in free stall alley & 1 & 0 & 0 & 0 \\
\hline Additional space for other areas, $\mathrm{m}^{2}$ & 1.35 & 43.20 & 220.50 & 0 \\
\hline No. of cows in holding area ${ }^{5}$ & 0 & 28 & 147 & 0 \\
\hline Groups of cows in holding area & 0 & 3 & 1 & 0 \\
\hline Available surface for milking parlor, ${ }^{6} \mathrm{~m}^{2}$ & 0 & 1.20 & 106.50 & 0 \\
\hline No. of individual maternity pens ${ }^{7}$ & 0 & 2 & 3 & 0 \\
\hline $\begin{array}{l}{ }^{1} \text { Waterers placed in the feed alley. } \\
{ }^{2} \text { Included alley at the back of the barn } \\
{ }^{3} \text { In the front stall row. } \\
{ }^{4} \text { Ratio } 1 \text { waterer } / 20 \text { cows. } \\
{ }^{5} \text { Ratio } 1.5 \mathrm{~m}^{2} / \text { cow. } \\
{ }^{6} \text { Excluding holding area. }\end{array}$ & $\mathrm{idth}=1 \mathrm{~m})$ & & & \\
\hline
\end{tabular}

In Figure 11, distributions of the 4 options of 2-row head-to-wall design are shown. They correspond to options A, B, C, and D in Table 3.

In both options of the 2-row head-to-wall distribution (Table 3), space is left over. When waterers are placed in all cross alleys such space might be used, for example, to access the holding area.

The 3-row distribution (Table 4) provides the most additional space for other areas. For example, that space would be sufficient to allow $1.5 \mathrm{~m}^{2}$ per cow in the holding area.

In the distribution with perpendicular rows (Table 5 ), there is no additional space as obtained with the other distributions. However, this distribution reduced the total area required $\left(907 \mathrm{~m}^{2}\right.$ vs. $>1,000 \mathrm{~m}^{2}$ in the other options).

Finally, in Table 6, the results for the previous options including waterers in cross alleys are summarized. The design of 2-row head-to-wall allows better adjustment between areas (not considering the design of perpendicular rows). With the considerations taken with respect to waterers, the distribution of 3 rows needs another crossover in front rows or employing the additional space for placing one of the waters. In this design, the holding pen and the milking parlor (herringbone $2 \times 6$ ) could be situated in the additional space. Instead, it could be included the maternity area with individual pens in this area or concentrate feeders could be situated there.

\section{CONCLUSIONS}

The algorithms presented in this study are effective tools for determining barn layout solutions as a function of herd size. They allow resolution of the most common barn designs: 2 rows, 3 rows, and rows perpendicular to the feed alley. The algorithms allow creation of designs for new construction, but can also be used for the study of alternatives for adaptation and extension of existing barns. The algorithms optimize use of space, obtaining specific solutions for each particular case. They allow different designs to be compared as a function of the values of the parameters used (e.g., cross alley width, maximum number of contiguous stalls).

They allow comparative evaluation of the different design options on the basis of advantages and disadvantages, prediction of possible problems arising in view of the specific characteristics of each farm, and analysis of potential for reuse, extension, or future modification of the housing.

In addition, these algorithms can be readily implemented in software for personal computers, greatly facilitating their application. 


\section{REFERENCES}

Anonymous. 2001. Interdisciplinary report: Housing Design for Cattle - Danish Recommendations. 3rd ed. The Danish Agricultural Advisory Center, Aarhus, Jutland, Denmark.

Adams, R. S., J. W. Comerford, S. A. Ford, R. E. Graves, C. W. Heald, A. J. Heinrichs, W. R. Henning, L. J. Hutchinson, V. A. Ishler, R. B. Keyser, M. L. O'Connor, L,. W. Specht, S. B. Spencer, G. A. Varga, and R. D. Yonkers. 1995. Dairy Reference Manual. NRAES-63. 3rd ed. Northeast Regional Agricultural Engineering Service, Ithaca, NY.

Alonso, M. 2002. Detalles constructivos en las salas de ordeño. Pages 311-341 in El ordeño en el ganado vacuno: Aspectos claves. Edición Mundi-Prensa, Madrid, Spain.

Arana, M. J., E. Ocaña, and A. Terradillos. 2002. Manual de instalaciones para explotaciones lecheras. Consejería de Agricultura y Pesca. Junta de Andalucía, Sevilla, Spain.

Bewley, J., R. W. Palmer, and D. B. Jackson-Smith. 2001. A comparison of free-stall use by modernized Wisconsin dairies. J. Dairy Sci. 84:528-541.

Bickert, W. G. 2000. Dairy facility decisions: How they are made in dairy housing and equipment systems, managing and planning for profitability. Pages 3-12 in Proc. Conf. Dairy Housing and Equipment Systems: Managing and Planning for Profitability, Camp Hill, PA. NRAES, Ithaca, NY.

Bickert, W. G., B. Holmes, K. Janni, D. Kammel, R. Stowell, and J. Zulovich. 2000. Dairy Free stall Housing and Equipment. 7th ed. MidWest Plan Service, Iowa State University, Ames.

Bowell, V. A., L. J. Rennie, G. Tierney, A. B. Lawrence, and M. J. Haskell. 2003. Relationships between building design, management system and dairy cow welfare. Anim. Welf. 12:547-552.

Buxadé Carbó, C. 1997. Principios e importancia de los alojamientos y de las instalaciones en ganadería en Alojamientos e Instalaciones. Edición Mundi-Prensa, Madrid, Spain.

Buxadé Carbó, C. 2002. El ordeño en el ganado vacuno: Aspectos clave. Mundi-Prensa, Madrid, Spain.

Callejo, A., V. Jimeno, and V. Díaz. 1997. Puntos clave en el alojamiento de vacas lecheras. Pages 359-392 in Vacuno de leche: Aspectos clave. Edición Mundi-Prensa, Madrid, Spain.

Carreira Pérez, X. C. 1996. Aloxamentos para gando vacún de leite. Consellería de Agricultura, Gandería e Montes, Xunta de Galicia, Santiago de Compostela, Spain.

Cook, N. B., and K. V. Nordlund. 2004. Behavioral needs of the transition cow and considerations for special needs facility design. Vet. Clin. North Am. Food Anim. Pract. 20:495-520.

DeVries, T. J., M. A. G. von Keyserlingk, and D. M. Weary. 2004. Effect of feeding space on the inter-cow distance, aggression, and feeding behavior of free-stall housed lactating dairy cows. J. Dairy Sci. 87:1432-1438.

Graves, R. E. 1995. Guideline for planning dairy free stall barns. Northeast Regional Agricultural Engineering Service, NRAES76 , Ithaca, NY.

Hansen, K., and C. N. Pallensen. 1998. Dairy cow pressure on selflocking feed barriers. Pages 312-319 in Proc. 4th Int. Dairy Housing Conf. Am. Soc. Agric. Eng., St. Joseph, MI.

Hansen, M. N. 2000. Comparison of the labour requirement involved in the housing of dairy cows in different housing systems. Acta Agric. Scand. A Anim. Sci. 50:153-160.

Karszes, J. 2000. Facilities and the bottom line. Pages 13-19 in Proc. Conf. Dairy Housing and Equipment Systems: Managing and Planning for Profitability, Camp Hill, PA. NRAES, Ithaca, NY.

Machado, L. C. P., D. L. Teixeira, D. M. Weary, M. A. G. von Keyserlingk, and M. J. Hotzel. 2004. Designing better water troughs: Dairy cows prefer and drink more from larger troughs. Appl. Anim. Behav. Sci. 89:185-193.

Menzies, F. D., and D. P. Mackie. 2001. Bovine toxic mastitis: Risk factors and control measures. Irish Vet. J. 54:30-37.

Stamer, E., N. Reinsch, and W. Junge. 2000. Traits of feeding behaviour for the estimation of roughage intake of dairy cows under loose housing conditions. Zuchtungskunde 72:340-358.

Stefanowska, J., D. Swiersta, J. V. van der Berg, and J. H. M. Metz. 2002. Do cows prefer a barn compartment with a grooved or slotted floor? J. Dairy Sci. 85:79-88.

Tucker, C. B., and D. M. Weary. 2001. Stall design: Enhancing cow comfort. Pages 155-168 in Proc. 2001 Western Canadian Dairy Seminar, University of Alberta, Edmonton. Advances in Dairy Technology. Volume 13. J. Kennelly, ed. Dept. Agric. Food Nutr. Sci., Univ. Alberta, Edmonton, Canada.

Tucker, C. B., D. M. Weary, and D. Fraser. 2004. Free-stall dimensions: Effects on preference and stall usage. J. Dairy Sci. $87: 1208-1216$.

Tyson, J. T. 2000. Farmstead layout: Putting the pieces together. Pages 49-56 in Proc. Conf. Dairy Housing and Equipment Systems: Managing and Planning for Profitability, Camp Hill, PA. NRAES, Ithaca, NY.

Veissier, I., J. Capdeville, and E. Delval. 2004. Cubicle housing systems for cattle: Comfort of dairy cows depends on cubicle adjustment. J. Anim. Sci. 82:3321-3337.

Vokey, F. J., C. L. Guard, H. N. Erb, and D. M. Galton. 2001. Effects of alley and stall surfaces on indices of claw and leg health in dairy cattle housed in a free-stall barn. J. Dairy Sci. 84:2686-2699.

von Borell, E. 1999. Animal welfare as a productive factor. Zuchtungskunde 71:473-481.

Wagner-Storch, A. M., R. W. Palmer, and D. W. Kammel. 2003. Factors affecting stall use for different free stall bases. J. Dairy Sci. $86: 2253-2266$. 